\title{
HIGH-LOADED FE-SUPPORTED CATALYST FOR THE THERMOCHEMICAL BTL-FT PROCESS: EXPERIMENTAL RESULTS AND MODELLING
}

\author{
Alberto Comazzi, ${ }^{1 *}$ Carlo Pirola, ${ }^{1}$ Claudia L. Bianchi, ${ }^{1}$ Federico Galli, ${ }^{1}$ Mariangela Longhi ${ }^{1}$ and Flavio Manenti ${ }^{2}$ \\ 1. Università degli Studi di Milano, Dipartimento di Chimica, Via Golgi, 19 - 20133 Milano, Italy \\ 2. Dipartimento di Chimica, Materiali e Ingegneria Chimica "Giulio Natta," Piazza Leonardo da Vinci, 32 - 20133, Milano, Italy
}

\begin{abstract}
The biomass-to-liquid Fischer-Tropsch (FT) process is an industrial process that converts bio-syngas in hydrocarbons ranging from $\mathrm{C}_{1}-\mathrm{C}_{100}$. Bio-syngas, a syngas mixture produced from biomass, is characterized by a $\mathrm{H}_{2} / \mathrm{CO}$ molar ratio in the range 1.0-1.5. An iron-based catalyst supported on silica for CO hydrogenation with $30 \mathrm{~g} / \mathrm{g}$ of metal was prepared, characterized by BET, SEM, TEM, TPR, XRD and tested at different temperatures and $\mathrm{H}_{2} / \mathrm{CO}$ ratios in a FT bench scale plant using a Packed Bed Reactor (PBR). The experimental results demonstrated that this catalyst is also suitable for low $\mathrm{H}_{2} / \mathrm{CO}$ ratios, since by increasing the inlet $\mathrm{H}_{2} / \mathrm{CO}$ ratio, the $\mathrm{CO}$ conversion increases, the product selectivity remains largely unchanged, and the catalyst shows a satisfactory stability as a function of time of stream (TOS). Based on the collected data, a rigorous multi-scale simulation of reactor behaviour was developed in order to support the experimental tests and predict the reactor yield and conversion. The elaborated kinetic model is based on the hypothesis that both FT and Water Gas Shift (WGS) reactions are active on the catalyst, and the calculated results agree with the obtained experimental data.
\end{abstract}

Keywords: Fischer-Tropsch, iron-based catalyst, BTL, kinetic model, WGS

\section{INTRODUCTION}

$\mathrm{F}$ ischer-Tropsch synthesis (FT) is a well-known industrial process which uses syngas (a mixture of $\mathrm{H}_{2}$ and $\mathrm{CO}$ ) to produce paraffins and olefins with different molecular masses while limiting the formation of methane and $\mathrm{CO}_{2}{ }^{[1]}$ Syngas can be manufactured from $\mathrm{CH}_{4}$, coal or, more recently, from biomass. ${ }^{[2]}$ In particular, bio-syngas, the syngas mixture produced from biomass, is different from the traditional syngas not only for its lower $\mathrm{H}_{2} / \mathrm{CO}$ but also because it contains $\mathrm{CO}, \mathrm{H}_{2}, \mathrm{CO}_{2}, \mathrm{CH}_{4}$, and $\mathrm{N}_{2}$ in various ratios. ${ }^{[3]}$ Starting from this mixture as feedstock, a cleaning process must be applied to remove impurities and produce clean bio-syngas which meets FT synthesis requirements.

The use of bio-syngas in FT synthesis is advantageous in terms of $\mathrm{CO}_{2}$ whole balance, and generates products without sulphur compounds or aromatic hydrocarbons, which is beneficial for environmental sustainability. ${ }^{[4]}$

The FT reaction usually requires catalysts based on iron or cobalt. ${ }^{[5]}$ It is very important to define the use of traditional syngas or bio-syngas. If bio-syngas $\left(\mathrm{H}_{2} / \mathrm{CO}=1 / 1\right)$ is feeding the reactor, iron catalysts can be used directly in the FT reactor, because iron is active for both FT and Water Gas Shift (WGS) reactions. The WGS reaction raises the $\mathrm{H}_{2} / \mathrm{CO}$ ratio closer to 2, the stoichiometric ratio of the FT reaction. ${ }^{[6]}$

Supported Fe-based catalysts have some advantages (greater surface area, better dispersion of generated heat, and better mechanical resistance) compared to the massive iron catalysts adopted in current FT industrial plants. ${ }^{[7,8]}$ The main drawback of this kind of catalyst is its lower activity compared to massive catalysts. For this reason, a high loading of active metal on the support is required. ${ }^{[7]}$

A detailed study concerning the optimized quantity of iron and promoters ( $\mathrm{K}$ and $\mathrm{Cu}$ ) on silica-supported catalysts, and a primary evaluation of the catalytic activity as a function of temperature and $\mathrm{H}_{2} / \mathrm{CO}$ ratio of feed was reported in two previous papers. ${ }^{[9,10]}$ The determined optimum metal quantities were $30 \mathrm{~g} / \mathrm{g}$ Fe, promoted with $\mathrm{K}(2.0 \mathrm{~g} / \mathrm{g})$ and $\mathrm{Cu}(3.75 \mathrm{~g} / \mathrm{g})$. Potassium improves $\mathrm{CO}$ adsorption. ${ }^{[11]}$ and copper promotes the reduction of iron oxide phases: from hematite $\left(\mathrm{Fe}_{2} \mathrm{O}_{3}\right)$ to magnetite $\left(\mathrm{Fe}_{3} \mathrm{O}_{4}\right)$, and then to iron metal or iron carbide, the active species for the FT reaction. ${ }^{[9,12,13]}$

A kinetic model was proposed and evaluated mainly on the basis of $\mathrm{CO}$ and $\mathrm{H}_{2}$ conversion. ${ }^{[14]}$ The same catalyst was characterized using TEM, SEM, TPR, and XRD.

In the present work, a detailed study concerning the BET surface area and porosity distribution is discussed in order to evaluate the effect of a high loading of metal on the $\mathrm{SiO}_{2}$ surface area, and the difference of the pore volume and pore area between the support without iron and the catalyst. $\mathrm{Fe}_{30} \mathrm{~K}_{2} \mathrm{Cu}_{3.75}$ was tested in a benchscale FT plant at different temperatures in the range of $220-260^{\circ} \mathrm{C}$ at $2.0 \mathrm{MPa}$ and at different $\mathrm{H}_{2} / \mathrm{CO}$ ratios $(1 ; 1.5 ; 2)$ in order to simulate different bio-syngas compositions. Based on the collected data, a rigorous multi-scale simulation of the FT synthesis reactor was developed in order to support the experiment and to predict both the reactor yield and conversion measured in the reactor; the kinetic parameters for both FT and WGS reactions were calculated with the obtained experimental data and fitted using model-based nonlinear regression techniques. The data calculated from this model was used for a detailed comparison concerning the product distribution using the Anderson-Schulz-Flory theory.

\section{EXPERIMENTAL}

All the percentages concerning the catalyst composition are on a mass basis, while the percentages concerning the CO conversion,

\footnotetext{
* Author to whom correspondence may be addresses.

E-mail address: alberto.comazzi@unimi.it

Can. J. Chem. Eng. 9999:1-7, 2015

(C) 2015 Canadian Society for Chemical Engineering

DOI 10.1002/cjce.22357

Published online in Wiley Online Library

(wileyonlinelibrary.com).
} 
product selectivity, and hydrocarbon yield are on a molar basis. The Fe-based catalyst is named $\mathrm{Fe}_{30} \mathrm{~K}_{2} \mathrm{Cu}_{3.75}$ where each number is the $\mathrm{g} / 100 \mathrm{~g}$ of $\mathrm{Fe}, \mathrm{K}$, and $\mathrm{Cu}$ present in the catalyst.

\section{Catalyst Preparation and Characterization}

\section{Catalyst synthesis}

The catalyst was prepared according to the traditional impregnation method, always using the same kind of commerciallyavailable silica support (Fluka product). ${ }^{[9]}$ The support was first pretreated in air at $120^{\circ} \mathrm{C}$ for $12 \mathrm{~h}$, followed by impregnation with an aqueous solution of $\mathrm{Fe}\left(\mathrm{NO}_{3}\right)_{3} \cdot 9 \mathrm{H}_{2} \mathrm{O}$ (Riedel de Haen), $\mathrm{KNO}_{3}$ (Merck), and $\mathrm{Cu}\left(\mathrm{CH}_{3} \mathrm{COO}\right)_{2} \cdot \mathrm{H}_{2} \mathrm{O}$ (Fluka). The catalyst was then placed in a vacuum oven at $40{ }^{\circ} \mathrm{C}$ at $36 \mathrm{rpm}$ for $24 \mathrm{~h}$. The sample was heated in air at $100{ }^{\circ} \mathrm{C}$ for $12 \mathrm{~h}$, followed by calcination at $500{ }^{\circ} \mathrm{C}$ for $4 \mathrm{~h}$.

\section{Catalyst characterization}

The catalyst's surface area and porosity distribution were determined by low temperature $\left(-196^{\circ} \mathrm{C}\right) \mathrm{N}_{2}$ adsorption using a Tristar II 3020 Micromeritics apparatus. Before measurement, samples were outgassed at $200{ }^{\circ} \mathrm{C}$ for $1 \mathrm{~h}$ in a nitrogen flux. Surface area and porosity distribution were calculated from nitrogen isotherms by BET and $\mathrm{BJH}$ theories using the instrumental software (Version 1.03).

SEM images were obtained using a Philips XL-30CP with backscattered electron detector. Conventional temperature-programmed reduction experiments (TPR) were performed on the calcined catalyst using a Thermoquest (Model TPR/D/O 1100). The samples were initially pre-treated in a flow of argon at $200{ }^{\circ} \mathrm{C}$ for $0.5 \mathrm{~h}$. After cooling to $50{ }^{\circ} \mathrm{C}$, the $\mathrm{H}_{2} / \mathrm{Ar}(5.1 \mathrm{~L} / \mathrm{L})$ reducing mixture was flowed through the sample at $30 \mathrm{~mL} \cdot \mathrm{min}^{-1}$, and the temperature was increased from 50 to $900{ }^{\circ} \mathrm{C}$ at a rate of $8{ }^{\circ} \mathrm{C} \cdot \mathrm{min}^{-1}$. The X-ray Powder Diffraction (XRD) patterns were taken with a computerized Philips PW1710 diffractometer using $\mathrm{CuK} \alpha$ emission, operating at $40 \mathrm{kV}$ and $20 \mathrm{~mA}$, step scan $1^{\circ} \cdot \min ^{-1}$, and $1 \mathrm{~s}$ counting time in the $2-40^{\circ} 2 \theta$ range at room temperature $\left(25^{\circ} \mathrm{C}\right)$.

\section{Apparatus for FT runs}

The Fischer-Tropsch reaction tests were carried out in a benchscale fixed-bed tubular reactor, using $1 \mathrm{~g}$ of fresh catalyst mixed with $1 \mathrm{~g}$ of diluting material $\left(\alpha-\mathrm{Al}_{2} \mathrm{O}_{3}\right.$, Fluka). This diluting material must be inert for FT while acting as a good thermal conductor to control the process temperature; the chosen catalyst/ diluting material ratio was optimized for the experimental setup used. ${ }^{[15]}$ The catalyst was initially activated in situ under a flow of $\mathrm{H}_{2} / \mathrm{CO}$ (ratio of $2 / 1, \mathrm{sl} / \mathrm{h} / \mathrm{g}_{\text {cat }}=3.0$ at $350^{\circ} \mathrm{C}, 0.4 \mathrm{MPa}$ for $4 \mathrm{~h}$ ). It is convenient to perform the activation operation starting with the calcined catalyst. Reduction using syngas is preferred to carbon monoxide alone. In this way, the same gas can be used both for the activation step and to feed the subsequent FT synthesis without influencing the catalytic activity of the sample. ${ }^{[9]}$ The catalyst was tested in a flow of syngas with $\mathrm{H}_{2} / \mathrm{CO}$ (molar ratios $2 / 1 ; 1.5 / 1 ; 1 / 1$; $\mathrm{sl} / \mathrm{h} / \mathrm{g}_{\text {cat }}=3.0$ ) using nitrogen as an internal analytical standard (flow $=5.0 \mathrm{NmL} \cdot \mathrm{min}^{-1}$ ) at $2.0 \mathrm{MPa}$ and different temperatures between $220-260^{\circ} \mathrm{C}$, for $70 \mathrm{~h}$. Analysis of the gas-phase products (the fraction of $\mathrm{C}_{1}-\mathrm{C}_{6}$ not condensed in the cold trap) was performed with an online micro-gas chromatograph (Agilent 3000A) equipped with two different columns: the first, a molsieves module, which can separate $\mathrm{CO}, \mathrm{N}_{2}$, and $\mathrm{CH}_{4}$ at a column temperature of $100^{\circ} \mathrm{C}$, and the second, a OV-1 module (stationary phase of polydymethylsiloxilane), which can separate $\mathrm{CO}_{2}$ and all hydrocarbons in the range $\mathrm{C}_{2}-\mathrm{C}_{6}$ at a column temperature of $45^{\circ} \mathrm{C}$. In this instrument, the gas sample is split into the two modules and analyzed simultaneously. Measurements were taken every 120 min during the run.

Liquid products were collected, during the complete reaction cycle $(70 \mathrm{~h})$, in a cold trap $(400 \mathrm{~mL})$, operating at $5{ }^{\circ} \mathrm{C}$ and at the same pressure of the reactor $(2.0 \mathrm{MPa})$, then analyzed by a gas chromatograph (Fisons-8000 series) equipped with a Porapack$\mathrm{Q}$ column (this being able to separate the $\mathrm{C}_{7}-\mathrm{C}_{30}$ hydrocarbon fraction). The column temperature was maintained at $60{ }^{\circ} \mathrm{C}$ for $1 \mathrm{~min}$ and then heated to $300{ }^{\circ} \mathrm{C}$ at $8{ }^{\circ} \mathrm{C} \cdot \mathrm{min}^{-1}$. The aqueous phase collected in the cold trap was analyzed by a TOC (Shimadzu $5000 \mathrm{~A}$ ) to identify the quantity of carbonaceous species dissolved in water. Using all the collected data, a mass molar balance resulted with a maximum error of $\pm 5 \%$ moles, for each run.

\section{RESULTS AND DISCUSSION}

\section{Catalyst Characterization}

All characterization analyses were performed on fresh catalysts, after the calcination step and before the activation treatment of the FT reactions.

The BET analysis evaluates the surface area of the support and the fresh catalyst. Figure 1 shows support $\left(\mathrm{SiO}_{2}\right)$ and catalyst $\left(\mathrm{Fe}_{30} \mathrm{~K}_{2} \mathrm{Cu}_{3.75}\right)$ isotherms. In both cases, they exhibit the typical form of a Type IV isotherm attributable to the presence of inkbottle pores. ${ }^{[16]}$ Specific surface area data are reported in Table 1.

A comparison of data shows that the introduction of iron, potassium, and copper into $\mathrm{SiO}_{2}$ reduces the surface area from 305 to $133 \mathrm{~m}^{2} \cdot \mathrm{g}^{-1}$ without a significant change of the micropore percentage. This reduction in surface area may be due to the diluting effect of the metals. ${ }^{[10]}$

More interesting modifications can be highlighted by comparing the distribution of porosity in terms of incremental pore volume and pore area, as shown in Figures $2 a$ and $2 b$, respectively, for the support $\left(\mathrm{SiO}_{2}\right)$ and the catalyst $\left(\mathrm{Fe}_{30} \mathrm{~K}_{2} \mathrm{Cu}_{3.75} / \mathrm{SiO}_{2}\right)$.

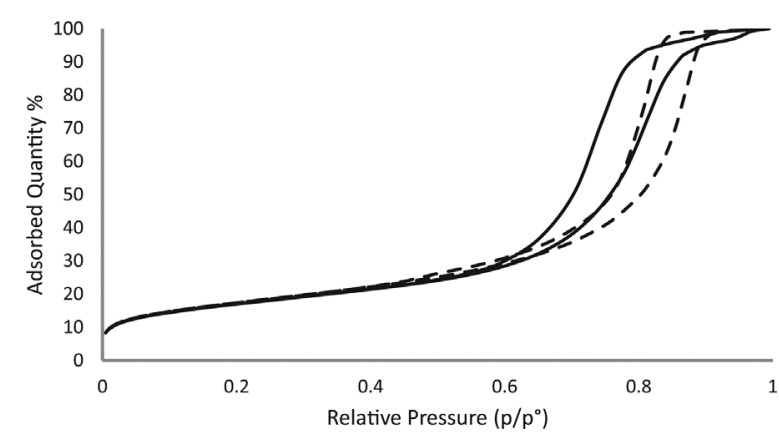

Figure 1. Nitrogen Isotherms. Dashed line: $\mathrm{SiO}_{2} ;$ continuous line: $\mathrm{Fe}_{30} \mathrm{~K}_{2} \mathrm{Cu}_{3.75}$.

Table 1. Specific surface area data

\begin{tabular}{lcc}
\hline & $\mathrm{SiO}_{2}$ & $\mathrm{Fe}_{30} \mathrm{~K}_{2} \mathrm{Cu}_{3.75}$ \\
\hline Specific Surface Area $\left(\mathrm{m}^{2} \mathrm{~g}^{-1}\right)$ & $305 \pm 2$ & $133 \pm 1$ \\
C Constant & 137 & 140 \\
Micropores \% & 6.5 & 7.5 \\
\hline
\end{tabular}



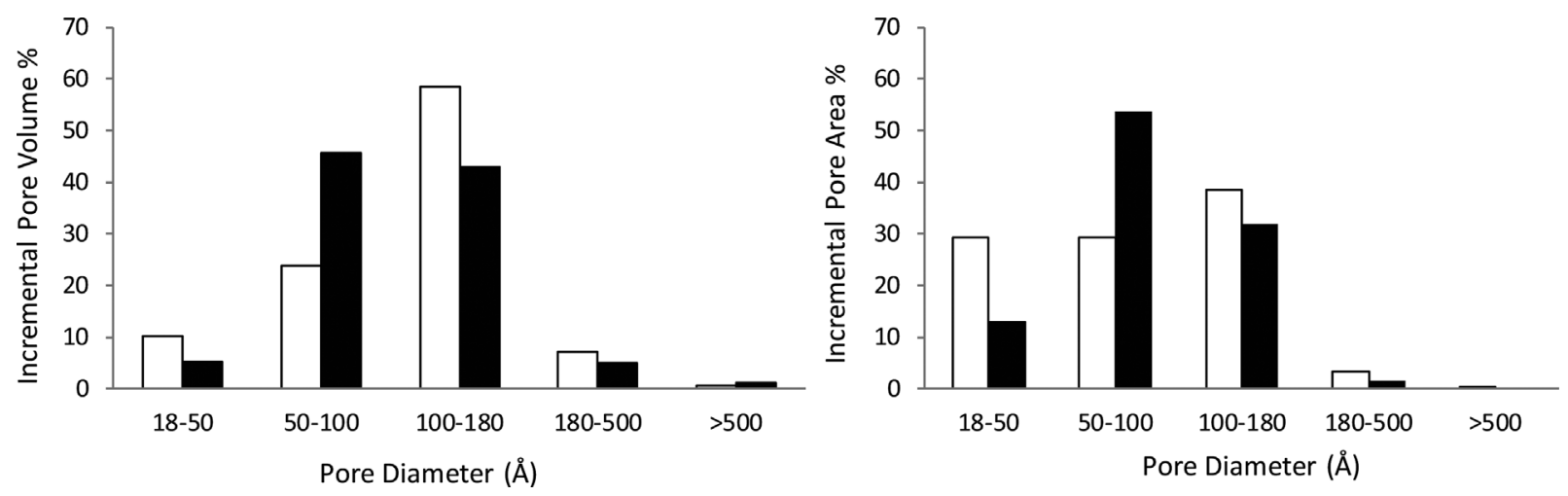

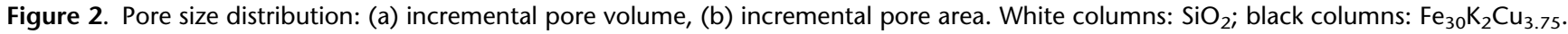

The presence of metals on the silica support induces a decrease of all mesoporous pores, except in the range $5-10 \mathrm{~nm}$, which instead increase by $92 \%$ and $84 \%$ for incremental pore volume (Figure 2a), and incremental pore area (Figure 2b), respectively. These heavy pore size distribution variations may be explained by considering that the insertion of metals may cause a partial occlusion of pores bigger than $5-10 \mathrm{~nm}$, by a "lining" of internal pore walls, thus forming smaller pores in the $5-10 \mathrm{~nm}$ range.

The TPR profile reported in the previous work shows the presence of two different reducible species: the first starting from hematite $\left(\mathrm{Fe}_{2} \mathrm{O}_{3}\right)$ to magnetite $\left(\mathrm{Fe}_{3} \mathrm{O}_{4}\right)$ at $230{ }^{\circ} \mathrm{C}$ (first peak), and the second from magnetite to metallic iron $(\alpha-\mathrm{Fe})$ at $550-750{ }^{\circ} \mathrm{C}$ (second and third peaks). ${ }^{[14]}$ The temperature difference between the two peaks, associated at the same transition, is due to different interaction with the Fe support. ${ }^{[17]}$ The $\mathrm{Cu}$ promotion shifts the reduction processes to a lower temperature. The role of $\mathrm{Cu}$ has also been verified in the improvement of iron oxide phase reduction in high iron-loaded catalysts. A suggested mechanism for this promotion effect is the migration of atomic hydrogen from reduced $\mathrm{Cu}$ sites to the iron oxide. ${ }^{[18]}$

The XRD analysis reported in previous work shows that before reductive activation, which is carried out directly in the reactor prior to the reactivity test, the iron is present as hematite $\left.\alpha-\mathrm{Fe}_{2} \mathrm{O}_{3}\right) \cdot{ }^{\left[{ }^{[1]}\right.}$ In the sample, the following diffraction peaks related to $2 \theta$ were found: $33^{\circ}, 35^{\circ}, 41^{\circ}, 50^{\circ}, 54^{\circ}, 62^{\circ}, 64^{\circ}$. These are indicative of the presence of hematite $\left(\alpha-\mathrm{Fe}_{2} \mathrm{O}_{3}\right)$.

SEM analyses were helpful for evaluating the morphology of catalysts with high metal iron loading and to verify metal dispersion. Both SEM $(25,31 \mathrm{Kx})$ and TEM images of the catalyst at different magnifications are shown in Figures $3 a-b, 4 a-b$.

It is possible to observe Fe aggregates uniformly distributed on the grain on the bare silica surface. Figure 4a highlights that iron occludes pores bigger than 5-10 nm, consequently increasing the pore volume and pore area in the range $5-10 \mathrm{~nm}$ for the catalyst sample, as previously discussed in the BET analysis.

\section{Fischer Tropsch Results}

The results obtained in the FT plant are presented in terms of $\mathrm{CO}$ conversion and selectivity toward $\mathrm{CO}_{2}, \mathrm{CH}_{4}$, light hydrocarbons $\left(<\mathrm{C}_{7}\right.$; having less than 7 carbon atoms), and heavy hydrocarbons $\left(>\mathrm{C}_{7}\right.$; having more than 7 carbon atoms). Moreover, the total yield of $\mathrm{C}_{2+}$ has been calculated as a combination of the $\mathrm{CO}$ conversion and product selectivity, disregarding methane and carbon dioxide because they are regarded as undesired byproducts of the FT process.

The FT data were collected from the start of the kinetic test until the reaction reached steady state (constant values of $\mathrm{CO}$ conversion and product selectivity) with an online analysis made every $2 \mathrm{~h}$, for a duration of $70 \mathrm{~h}$. In order to evaluate catalyst stability, $\mathrm{CO}$ conversion and selectivity toward products as a function of TOS are reported in Figures 5, 6a-c.

The results in Figure 5 show that the catalyst exhibits satisfactory stability in terms of reactant conversion as a function

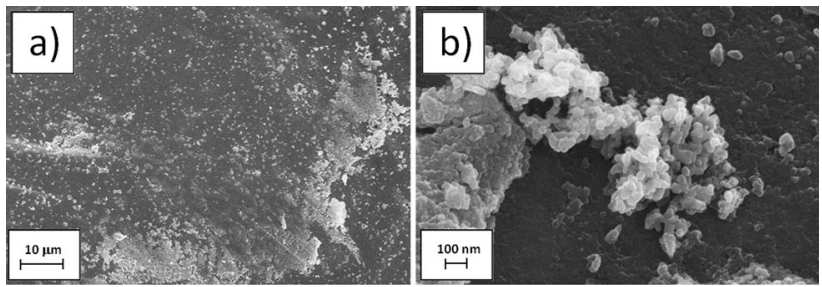

Figure 3. SEM analysis of $\mathrm{Fe}_{30} \mathrm{~K}_{2} \mathrm{Cu}_{3.75}$.
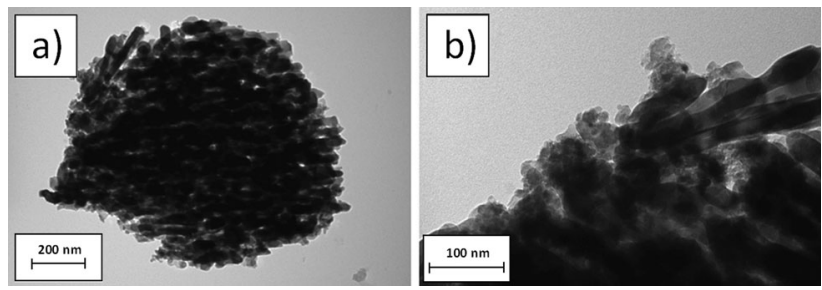

Figure 4. TEM analysis of $\mathrm{Fe}_{30} \mathrm{~K}_{2} \mathrm{Cu}_{3.75}$.

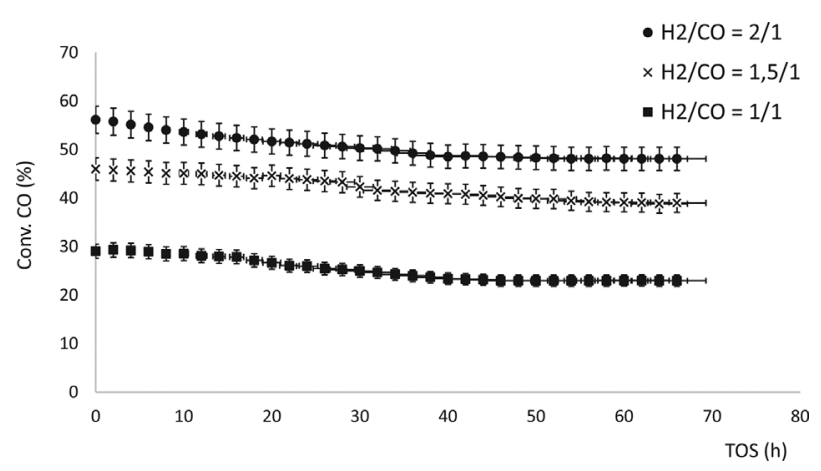

Figure 5. $\mathrm{CO}$ conversion as a function of TOS: $(\bullet) \mathrm{H}_{2} / \mathrm{CO}=2 / 1 ;(X)$ $\mathrm{H}_{2} / \mathrm{CO}=1.5 / 1 ;(\boldsymbol{\square}) \mathrm{H}_{2} / \mathrm{CO}=1 / 1 . \mathrm{T}=250^{\circ} \mathrm{C}, \mathrm{P}=2.0 \mathrm{MPa}$. 

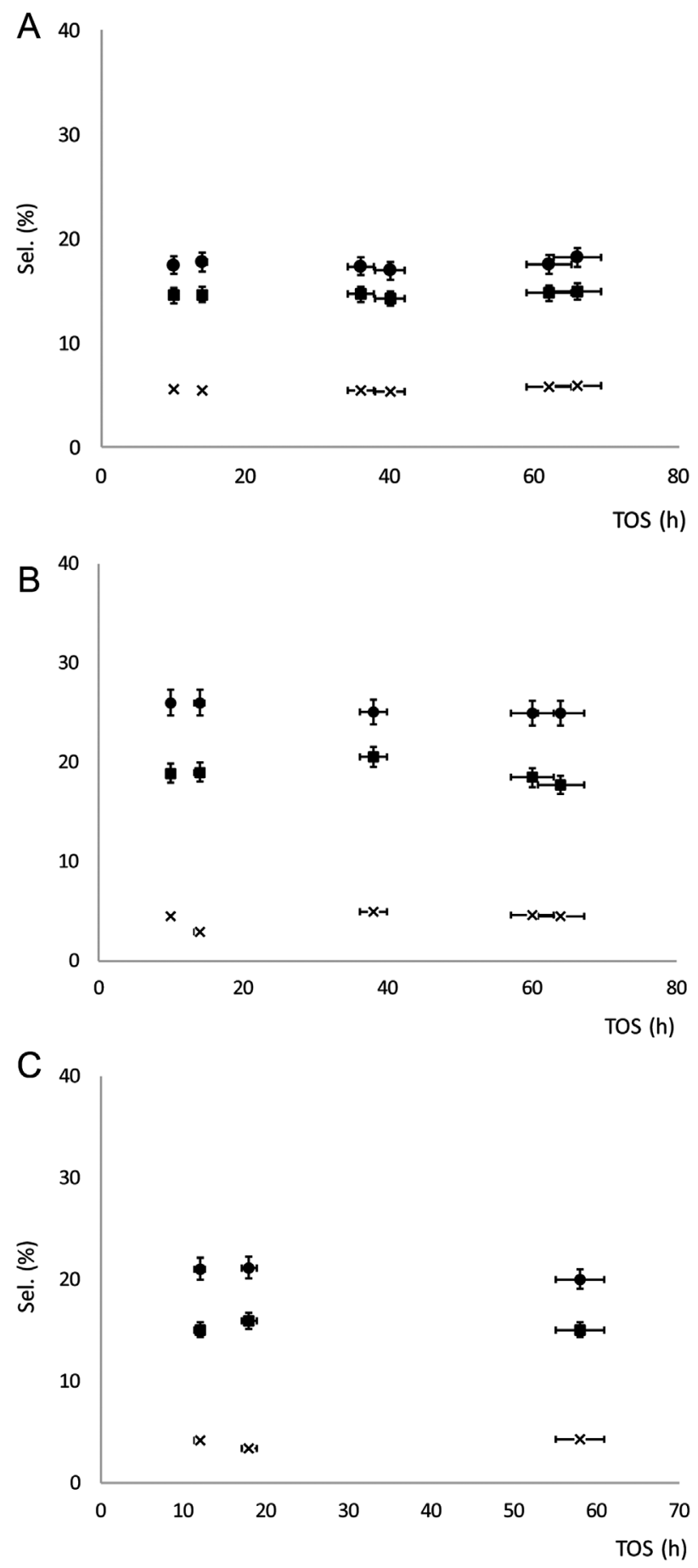

Figure 6. Selectivity to $(\bullet)<\mathrm{C}_{7} ;(\boldsymbol{\square}) \mathrm{CO}_{2} ;(\mathrm{X}) \mathrm{CH}_{4}$ with $\mathrm{H}_{2} / \mathrm{CO}=2 / 1$ (a), $\mathrm{H}_{2} / \mathrm{CO}=1,5 / 1$ (b), $\mathrm{H}_{2} / \mathrm{CO}=1 / 1$ (c). $\mathrm{T}=250^{\circ} \mathrm{C}, \mathrm{P}=2.0 \mathrm{MPa}$.

of TOS. Moreover, CO conversion is strongly influenced by the ${ }_{2} / \mathrm{CO}$ reactor feed and reaches a stable value after $40 \mathrm{~h}$ from the start of the kinetic test.

The selectivity is stable as a function of TOS and is constant from the start of the kinetic test. Moreover, the selectivity towards the reaction products $\left(\mathrm{CO}_{2}, \mathrm{CH}_{4}\right.$, and heavy hydrocarbons $)$ is independent of the $\mathrm{H}_{2} / \mathrm{CO}$ ratio, remaining essentially unchanged for $1<\mathrm{H}_{2} / \mathrm{CO}<2$, in agreement with other works. ${ }^{[19]}$

In order to compare the catalytic performance at the different conditions tested, the $\mathrm{C}_{2+}$ yield at different reaction temperatures and $\mathrm{H}_{2} / \mathrm{CO}$ ratios is reported in Figure 7.

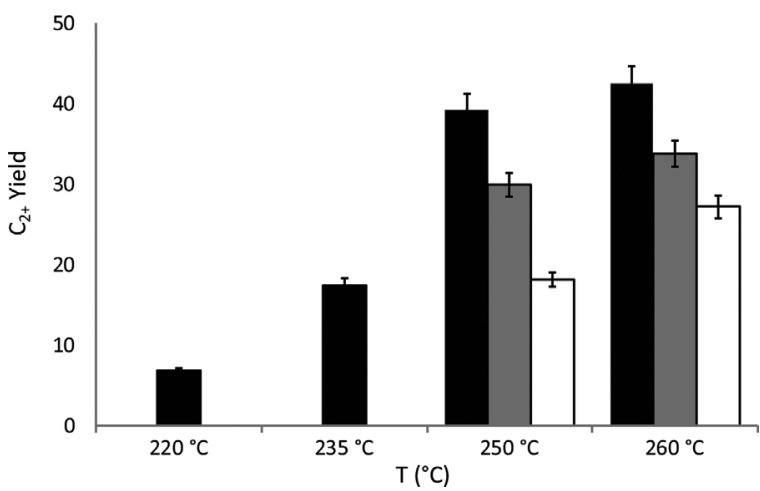

Figure 7. $\mathrm{C}_{2+}$ yield at different temperature and $\mathrm{H}_{2} / \mathrm{CO}=2 / 1$ (black columns), $\mathrm{H}_{2} / \mathrm{CO}=1.5 / 1$ (grey columns), $\mathrm{H}_{2} / \mathrm{CO}=1 / 1$ (white columns).

The $\mathrm{C}_{2+}$ yield is calculated as follows:

$C_{2+\text { yield }}=0.01\left(<C_{7 \text { selectivity }}+>C_{7 \text { selectivity }}\right) C_{\text {conversion }}$

As Figure 7 shows, the $\mathrm{H}_{2} / \mathrm{CO}$ ratio influences the $\mathrm{C}_{2+}$ yield at the same temperature, i.e. $250-260^{\circ} \mathrm{C}$. The catalyst also shows good performance at low $\mathrm{H}_{2} / \mathrm{CO}(<2 / 1)$, which is the stoichiometry for the FT reaction.

The probability of chain growth $(\alpha)$ is one of the most significant parameters in FT, and it is calculated from the experimental results using the Anderson-Schulz-Flory distribution. In Table 2, the $\alpha$ values are reported for the catalyst at $250-260{ }^{\circ} \mathrm{C}$ and different $\mathrm{H}_{2}$ / CO ratios for the range $\mathrm{C}_{1}-\mathrm{C}_{30}$.

The probability of chain growth remains steady in the range $250-260^{\circ} \mathrm{C}$ and $1<\mathrm{H}_{2} / \mathrm{CO}<2$. The temperature range considered was limited because this parameter was already optimized for this kind of catalyst in our previous work. ${ }^{[9]}$

Following the kinetic tests, gas-chromatographic analyses of the heavy organic fraction collected in the cold trap were performed. The molar fractions of the products at different $\mathrm{H}_{2} / \mathrm{CO}$ ratios and $250{ }^{\circ} \mathrm{C}$ are reported in Figure 8.

Table 2. $\alpha$ values for the sample $\mathrm{Fe}_{30} \mathrm{~K}_{2} \mathrm{Cu}_{3.75}$ at $\mathrm{T}=250-260^{\circ} \mathrm{C}$

\begin{tabular}{lcc}
\hline $\mathrm{H}_{2} / \mathrm{CO}$ & $\begin{array}{c}\alpha_{\mathrm{C} 1-\mathrm{C} 30} \\
T=250{ }^{\circ} \mathrm{C}\end{array}$ & $\begin{array}{c}\alpha_{\mathrm{C} 1-\mathrm{C} 30} \\
T=260^{\circ} \mathrm{C}\end{array}$ \\
\hline $2 / 1$ & 0.74 & 0.73 \\
$1.5 / 1$ & 0.76 & 0.73 \\
$1 / 1$ & 0.76 & 0.74 \\
\hline
\end{tabular}

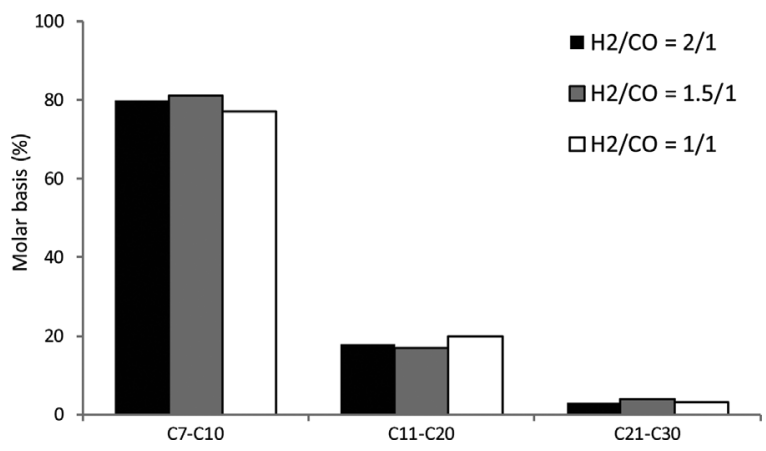

Figure 8. Mol\% of $\mathrm{C}_{7-10}, \mathrm{C}_{11-20}$, and $\mathrm{C}_{20-30}$ lumps with different $\mathrm{H}_{2} / \mathrm{CO}$ ratios at $\mathrm{T}=250^{\circ} \mathrm{C}$. 
In order to simplify the obtained results, the molar fractions of the heavy organic phase were grouped into three different groups, $\mathrm{C}_{7-10}, \mathrm{C}_{11-20}$, and $\mathrm{C}_{20-30}$. The results of the $\mathrm{GC}$ analyses confirm that the molar distribution of the $\mathrm{C}_{7-10}, \mathrm{C}_{11-20}$, and $\mathrm{C}_{20-30}$ groups is not strongly influenced by the $\mathrm{H}_{2} / \mathrm{CO}$ ratio; this trend is also confirmed at the different reaction temperatures tested.

\section{KINETIC MODEL}

A key point in the proposed kinetic interpretation is related to the co-presence of FT and WGS reactions, both active on the catalyst. This hypothesis was already verified and discussed for these kind of supported iron-based catalysts in our previous work. ${ }^{\left[{ }^{9]}\right.}$ The rate constants can be obtained via model-based regression of both reactions, which we will refer to as $\mathrm{k}_{\mathrm{FT}}$ (FT reaction) and $\mathrm{k}_{\mathrm{WGS}}$ (WGS reaction) hereafter.

The modelling work is based on the steady state experimental data obtained at different temperatures and $\mathrm{H}_{2} / \mathrm{CO}$ ratios, shown in Figures 5-6, which confirm that the catalyst is not deactivated as a function of TOS. The constructed kinetic model allows us to simulate the performance of these types of catalysts at different temperatures and different syngas feeding ratios.

The novelty of this work with respect to the previous study is that the probability of chain growth and the catalyst efficiency are taken into account for the evaluation of the kinetic parameters. $^{[14]}$

Two equations, suitable for fixed bed reactors with iron-based catalysts, which express the rate of the FT and WGS reactions used for the regression are reported. ${ }^{[20]}$

$$
\begin{aligned}
& \mathrm{r}_{\mathrm{FT}}=\mathrm{k}_{\mathrm{FT}} \frac{\mathrm{P}_{\mathrm{CO}} \mathrm{P}_{\mathrm{H}_{2}}}{\mathrm{P}_{\mathrm{CO}}+\mathrm{a}_{\mathrm{FT}} \mathrm{P}_{\mathrm{H}_{2} \mathrm{O}}+\mathrm{b}_{\mathrm{FT}} \mathrm{P}_{\mathrm{CO}_{2}}} \quad \mathrm{k}_{\mathrm{FT}}=\left[\frac{\mathrm{mol}}{\mathrm{Kg} \text { cat } \cdot \mathrm{Pa} \cdot \mathrm{s}}\right] \\
& \mathrm{r}_{\mathrm{WGS}}=\mathrm{k}_{\mathrm{WGS}} \frac{\mathrm{P}_{\mathrm{CO}} \mathrm{P}_{\mathrm{H}_{2} \mathrm{O}}-\mathrm{P}_{\mathrm{H}_{2}} \mathrm{P}_{\mathrm{CO}_{2}} / \mathrm{K}_{\mathrm{p}}}{\mathrm{P}_{\mathrm{CO}}+\mathrm{a}_{\mathrm{WGS}} \mathrm{P}_{\mathrm{H}_{2} \mathrm{O}}+\mathrm{b}_{\mathrm{WGS}} \mathrm{P}_{\mathrm{CO}_{2}}} \quad \mathrm{k}_{\mathrm{WGS}}=\left[\frac{\mathrm{mol}}{\mathrm{Kg} \text { cat } \cdot \mathrm{Pa} \cdot \mathrm{s}}\right]
\end{aligned}
$$

The reaction rate is a function of the partial pressures of the reactants $\left(\mathrm{CO}, \mathrm{H}_{2}, \mathrm{H}_{2} \mathrm{O}\right.$, and $\mathrm{CO}_{2}$ ), the experimentally determined $\mathrm{K}_{\mathrm{p}}$, and the adjustable parameters $\left(\mathrm{k}_{0, \mathrm{i}}, \mathrm{a}_{\mathrm{FT} / \mathrm{WGS}}, \mathrm{b}_{\mathrm{FT} / \mathrm{WGS}}\right)$. The constant $\mathrm{k}_{0, \mathrm{i}}$ is dependent on temperature, based on the Arrhenius equation. The equilibrium constant $\mathrm{Kp}$ is expressed as follows:

$\mathrm{K}_{\mathrm{p}}=\mathrm{e}\left(\frac{4578}{\mathrm{~T}}-4.33\right)$

The regression of the parameter values $\mathrm{k}_{0, \mathrm{i}}$ was obtained with MATLAB (version R2014b) using literature values for $\mathrm{k}_{0, \mathrm{FT}}$, $\mathrm{k}_{0, \mathrm{WGS}}, \mathrm{a}_{\mathrm{FT}}, \mathrm{a}_{\mathrm{WGS}}, \mathrm{b}_{\mathrm{FT}}$, and $\mathrm{b}_{\mathrm{WGS}}$ for the first attempt. ${ }^{[21]}$ The software allows the regression of the parameters $\mathrm{k}_{0, \mathrm{FT}}, \mathrm{k}_{0, \mathrm{WGS}}, \mathrm{a}_{\mathrm{FT}}$, $a_{W G S}, b_{F T}$, and $b_{W G S}$ by setting a weighted least-squares type objective function that must be minimized as much as possible up to a tolerance of $10^{-6}$ (basis MATLAB tolerance); the objective function is defined as follows:

Fobj $=\sum_{\mathbf{j}=1}^{\mathrm{N}}\left(X_{i, \text { exper }}-X_{i, \text { model }}\right)^{2}$

where $X_{i, \text { exper }}$ is the molar fraction of the $i^{\text {th }}$ species measured experimentally during the kinetic runs, and $\mathrm{X}_{\mathrm{i}}$, model is the molar fraction of the $\mathrm{i}^{\text {th }}$ species simulated by the model.

The probability of chain growth is given by the Lox and Froment correlation for iron-based catalysts. ${ }^{[22]}$

$\alpha_{A S F}=\frac{k_{1} P_{\mathrm{CO}}}{k_{1} P_{C O}+k_{2} P_{H_{2}}+k_{3}}$

The problems due to the diffusion of reactants on the catalyst surface are not negligible and must be taken into account; the efficiency of the catalyst is expressed as reported in Equation (7)..$^{[21]}$

$\eta_{j}=\frac{\int_{O}^{V_{\mathrm{p}}} r_{\mathrm{j}}\left(T, P_{i}\right) g_{c a t}^{d V}}{V_{p} \cdot r_{j}\left(T_{s} P_{i, s}\right) g_{c a t}}$

The list of symbols used in Equations (2-7) is reported in the Nomenclature section.

\section{Model Results}

The kinetic parameters were regressed considering all the experimental results simultaneously at different $\mathrm{H}_{2} / \mathrm{CO}$ feed ratios and temperatures after reaching steady state. The results are summarized in Table 3 . The regressed constant and the activation energy for both the FT and WGS reactions show close agreement with the parameters found in the literature for a similar catalytic system, based on an iron catalyst.

The kinetic model constructed with numerical constants regressed from the experimental data is able to simulate the $\mathrm{Fe}_{30} \mathrm{~K}_{2} \mathrm{Cu}_{3.75}$ performance at the different temperatures and $\mathrm{H}_{2} / \mathrm{CO}$ ratios tested. All the comparisons of the model and the experimental data refer to the data measured at steady state (after $70 \mathrm{~h})$.

Comparisons of the experimental data and the model as functions of temperature at $\mathrm{H}_{2} / \mathrm{CO}$ ratio $=2 / 1$ are reported in Figures $9 \mathrm{a}-\mathrm{b}$.

The molar fractions for each product are not reported in Figure 9 because the light and heavy hydrocarbons are sorted into different groups: $\mathrm{CO}, \mathrm{H}_{2}, \mathrm{H}_{2} \mathrm{O}, \mathrm{CO}_{2}, \mathrm{CH}_{4}$, and $\mathrm{C}_{3-4}, \mathrm{C}_{5-10}, \mathrm{C}_{11+}$.

In the first two columns $\left(\mathrm{X}_{\mathrm{CO}}\right.$ and $\left.\mathrm{X}_{\mathrm{H} 2}\right)$ the reactant conversions are reported, and in the other columns the molar fractions of reactants, products, and different lumps are also reported. As outlined in Figure 9, the model shows an accurate prediction of the trends measured experimentally.

In order to evaluate the model validity for factors concerning the product selectivity in greater detail, the experimental AndersonSchulz-Flory product distribution was compared with the

\begin{tabular}{|c|c|c|c|c|c|c|c|c|}
\hline & $\begin{array}{c}\mathrm{K}_{0, \mathrm{FT}} \\
(\mathrm{mol} / \mathrm{Kg} \cdot \mathrm{Pa} \cdot \mathrm{s})\end{array}$ & $\begin{array}{c}\mathrm{K}_{0, \mathrm{wGS}} \\
(\mathrm{mol} / \mathrm{Kg} \cdot \mathrm{Pa} \cdot \mathrm{s})\end{array}$ & $\begin{array}{c}\mathrm{Ea}_{\mathrm{FT}} \\
(\mathrm{kJ} / \mathrm{mol})\end{array}$ & $\begin{array}{l}\text { EawGs } \\
(\mathrm{kJ} / \mathrm{mol})\end{array}$ & $\begin{array}{l}a_{\mathrm{FT}} \\
(-)\end{array}$ & $\begin{array}{c}a_{W G S} \\
(-)\end{array}$ & $\begin{array}{l}\mathrm{b}_{\mathrm{FT}} \\
(-)\end{array}$ & $\begin{array}{c}\mathrm{b}_{\mathrm{WGS}} \\
(-)\end{array}$ \\
\hline Present work & 9.6 & $9.31 \cdot 10^{6}$ & 85.7 & 136 & 4.71 & 24.47 & 0.32 & 0 \\
\hline Rafiee $^{[21]}$ & 8.58 & $9.33 \cdot 10^{6}$ & 86 & 132 & 4.8 & 21 & 0.33 & 0 \\
\hline
\end{tabular}

Table 3. Comparison between literature and regressed parameters 

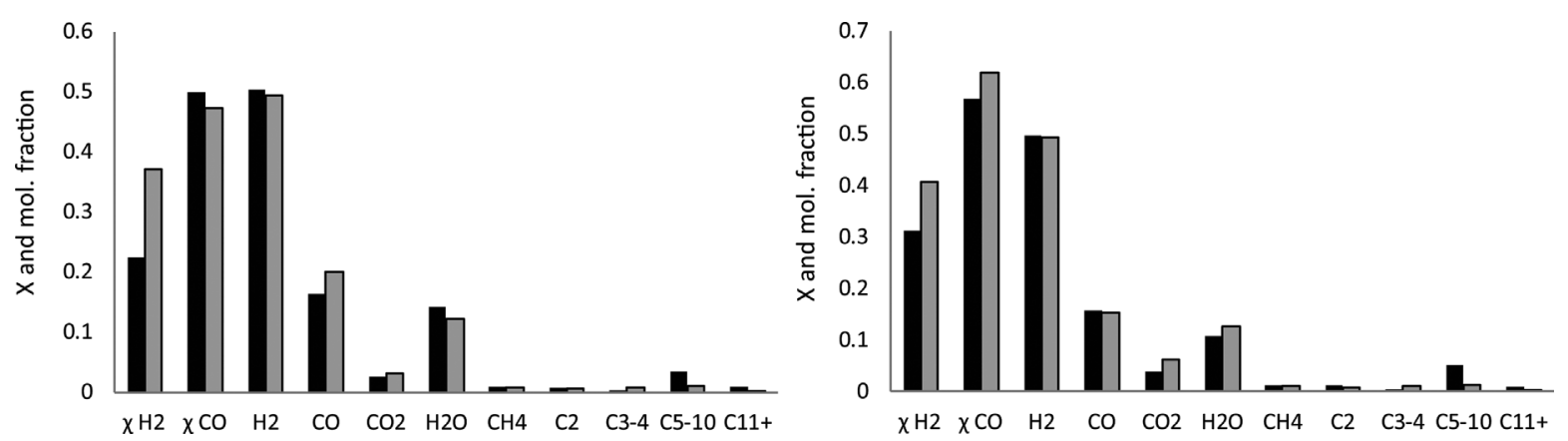

Figure 9. (a) $\mathrm{T}=250^{\circ} \mathrm{C}$; (b) $\mathrm{T}=260^{\circ} \mathrm{C}$. Black columns: experimental data, grey columns: model data. $\mathrm{H}_{2} / \mathrm{CO}$ ratio $=2 / 1$.
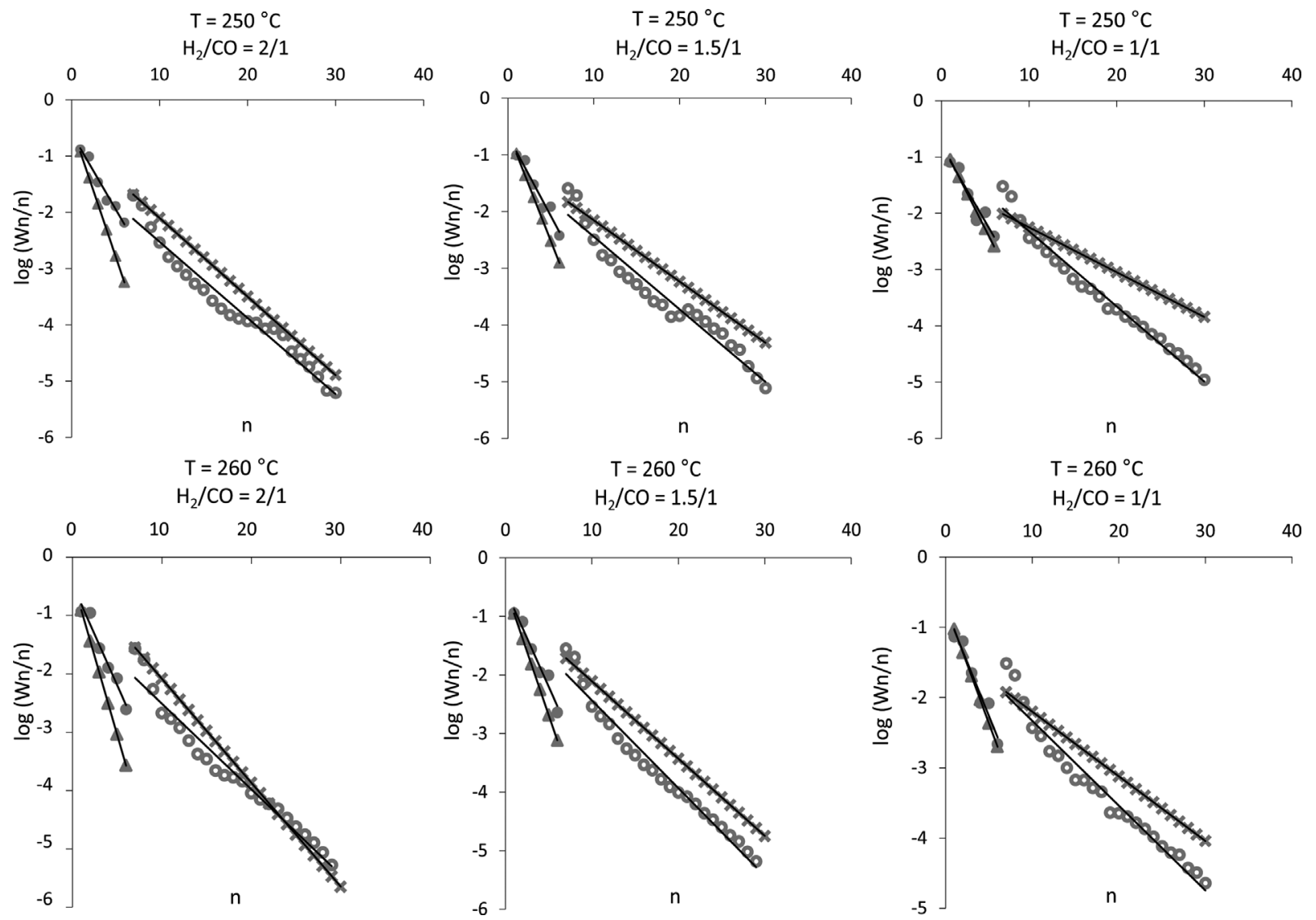

Figure 10. ASF diagram: $(\bullet)$ experimental $C_{1}-C_{6} ;(0)$ experimental $C_{7}-C_{30} ;(\Delta)$ simulated $C_{1}-C_{6} ;(X)$ simulated $C_{7}-C_{30}$.

modelled distribution. The Anderson-Schultz-Flory diagrams obtained using results predicted by the model at different temperatures and $\mathrm{H}_{2} / \mathrm{CO}$ feed ratios are reported in Figure 10.

Figure 10 confirms the close agreement of the constructed kinetic model with the measured experimental data, also in terms of detailed product distribution in the range $C_{1}-C_{30}$.

\section{CONCLUSIONS}

A supported iron-based catalyst for FT with a high loading of iron was synthesized, characterized, and tested. The study of the BET surface area and porosity distribution confirms that the introduction of iron, potassium, and copper into $\mathrm{SiO}_{2}$ reduces the surface area from 305 to $133 \mathrm{~m}^{2} \mathrm{~g}^{-1}$ without a modification of micropore percentage, but induces a decrease of all mesoporous pores except for those with diameters of 5-10 $\mathrm{nm}$, which instead increase by $92 \%$ and $84 \%$ for incremental pore volume and incremental pore area, respectively.

The $\mathrm{Fe}_{30} \mathrm{~K}_{2} \mathrm{Cu}_{3.75}$ catalyst is also active for the FT conversion of syngas with a $\mathrm{H}_{2} / \mathrm{CO}$ ratio similar to the ratio of bio-syngas $\left(\mathrm{H}_{2} /\right.$ $\mathrm{CO}=1$ ). The catalyst shows good stability as a function of TOS and exhibits a gradual drop of CO conversion from $49.8 \%$ to $23.0 \%$ at $250{ }^{\circ} \mathrm{C}$ when $\mathrm{H}_{2} / \mathrm{CO}<2$. Selectivity toward the products remains essentially unchanged at a constant temperature, with about $60 \%$ toward heavy products and $19 \%$ toward light products at $250{ }^{\circ} \mathrm{C}$ and $\mathrm{H}_{2} / \mathrm{CO}=2 / 1$.

The selectivity to heavy products decreases with increasing reaction temperature, while the probability of chain growth as a function of the $\mathrm{H}_{2} / \mathrm{CO}$ ratio and temperature remains unchanged. 
The developed model shows close agreement with the experimental data obtained at different $\mathrm{H}_{2} / \mathrm{CO}$ ratios tested for both reactant conversion and product selectivity.

\section{NOMENCLATURE}

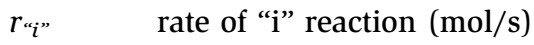

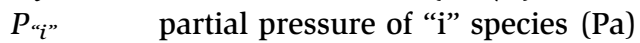

$a$ "i", $b$ " $i$ " regressed constants of "i" reaction

$k^{\prime \prime} i$ " kinetic constant of "i" reaction $(\mathrm{mol} / \mathrm{Kg} \cdot \mathrm{Pa} \cdot \mathrm{s})$

Kp equilibrium constant

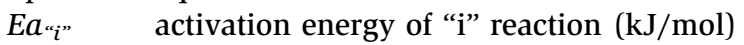

$F_{o b j} \quad$ objective function

$X{ }{ }_{i}$ " $\quad$ molar fraction "i" species

$\alpha_{A S F} \quad$ probability of chain growth

$T \quad$ bulk temperature (K)

$T_{s} \quad$ surface temperature $(\mathrm{K})$

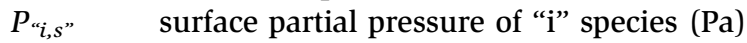

gcat mass of catalyst (g)

\section{REFERENCES}

[1] Q. Zhang, J. Kang, Y. Wang, Chem. Cat. Chem. 2010, 2, 1030.

[2] M. Hadnadev-Kostic, J. Tatjana, T. Vulic, R. MarinkovicNeducin, A. D. Nikolic, B. Jovic, Serb. Chem. Soc. 2011, 76, 1661 .

[3] A. V. Bridgewater, Thermochemical Processing of Biomass, 1st edition, Butterworths, London 1984.

[4] J. Hu, F. Yu, Y. Lu, Catalysts 2012, 2, 303.

[5] J. Yanga, W. Ma, D. Chen, A. Holmen, B. H. Davis, App. Catal. A-Gen. 2014, 470, 250.

[6] D. H. Chun, H. T. Lee, J. I. Yang, H. J. Kim, J. H. Yang, J. C. Park, B. K. Kim, H. Jung, Catal. Lett. 2014, 142, 452.

[7] K. Cheng, V. V. Ordomsky, M. Virginie, B. Legras, P. A. Chernavskii, V. O. Kazak, C. Cordier, S. Paul, Ye Wang, A. Y. Khodakov, App. Catal. A-Gen. 2014, 488, 66.

[8] K. Keyvanloo, W. C. Hecker, B. F. Woodfield, C. H. Bartholomew, J. Catal. 2014, 319, 220.

[9] C. Pirola, C. L. Bianchi, A. Di Michele, P. Diodati, S. Vitali, V. Ragaini, Catal. Lett. 2009, 131, 294.

[10] C. Pirola, C. L. Bianchi, A. Di Michele, S. Vitali, V. Ragaini, Cat. Comm. 2009, 10, 823.

[11] G. P. Van Der Laan, A. A. C. M. Beenackers, Catal. Rev. 1999, $41,255$.

[12] A. N. Pour, M. R. Housaindokht, S. F. Tayyari, J. Nat. Gas. Chem. 2010, 19, 362.

[13] V. Ramana, R. Pendyala, G. Jacobs, H. H. Hamdeh, W. D. Shafer, D. E. Sparks, S. Hopps, B. H. Davis, Catal. Lett. 2014, 144, 1624.

[14] C. Pirola, C. L. Bianchi, A. Di Fronzo, A. Comazzi, F. Manenti, Chem. Eng. Tran. 2014, 37, 595.

[15] C. L. Bianchi, C. Pirola, V. Ragaini, Catal. Comm. 2006, 7, 669.

[16] K. S. W. Sing, D. H. Everett, R. A. W. Haul, L. Moscou, R. A. Pierotti, J. Rouquerol, T. Siemieniewska, Pure \& Appl. Chem. 1985, 57, 603.

[17] D. B. Bukur, K. Okabe, M. P. Rosynek, C. Li, D. Wang, K. R. P. M. Rao, G. P. Huffman, J. Catal. 1995, 155, 353.

[18] Y. Jin, A. K. Datye, J. Catal. 2000, 196, 8.
[19] S. Abello, D. Montane, Chem. Sus. Chem. 2006, 4, 1538.

[20] W. H. Zimmerman, D. B. Bukur, Can. J. Chem. Eng. 1990, 68, 292.

[21] A. Rafiee, Optimal Design Issues of a Gas-to-Liquid Process, PhD Thesis, Norwegian University of Science and Technology, Trondheim, Norvegy 2012, p. 61.

[22] E. S. Lox, G. F. Froment, Ind. Eng. Chem. Res. 1993, 32, 71.

Manuscript received February 3, 2015; revised manuscript received March 27, 2015; accepted for publication March 31, 2015. 